Article

\title{
Assessment of Antidepressant Effect of the Aerial Parts of Micromeria myrtifolia Boiss. \& Hohen on Mice
}

\author{
Esra Küpeli Akkol ${ }^{1, * \mathbb{D}}$, Fatma Tuğçe Gürağaç Dereli ${ }^{1}$ and Mert Ilhan ${ }^{2}$ \\ 1 Department of Pharmacognosy, Faculty of Pharmacy, Gazi University, Etiler, Ankara 6330, Turkey; \\ ecztugceguragac@gmail.com \\ 2 Department of Pharmacognosy, Faculty of Pharmacy, Van Yüzüncü Yıl University, Tuşba/Van 65080, Turkey; \\ eczmertilhan@gmail.com \\ * Correspondence: esrak@gazi.edu.tr; Tel.: +90-312-202-3185
}

Academic Editor: Eduardo Sobarzo-Sánchez

Received: 10 April 2019; Accepted: 14 May 2019; Published: 15 May 2019

check for updates

\begin{abstract}
The currently available antidepressant agents necessitate the development of newer alternatives because of their serious adverse effects and costs. Traditional medicinal knowledge is likely the key that opens the door to discover new medicines. In Turkish folk medicine, the infusion prepared from aerial parts of Micromeria myrtifolia Boiss. \& Hohen is used as pleasure and medicinal tea for its relaxing action. The present research was conceived to confirm the antidepressant's potential of this traditional medicinal plant. In this process, first of all, the collected and shade-dried aerial parts of M. myrtifolia were powdered and then, extracted using solvents with different polarity as follows; $n$-hexane, ethyl acetate (EtOAc), and methanol (MeOH). The antidepressant activity of the extracts was evaluated by using several in vivo and in vitro experimental models of depression. When the data obtained from the control and experimental groups were compared, it was determined that the $\mathrm{MeOH}$ extract was the most active. The active components of this extract were isolated and identified utilizing various chromatographic separation techniques. The $\mathrm{MeOH}$ extract was applied to reversed phase (RP-18) column chromatography to obtain five main fractions and they were tested on antidepressant activity models. The isolated compounds from the obtained fractions were elucidated as rosmarinic acid (1), myricetin (2), apigenin (3), and naringenin (4) which were assumed to be responsible for the antidepressant activity of the aerial parts. According to the results, rosmarinic acid, myricetin, apigenin, and naringenin showed statistically significant activity on forced swimming test and tetrabenazine-induced ptosis models, whereas only rosmarinic acid showed statistically significant activity on the tail suspension test. Apigenin displayed the highest inhibitory activity on MAO A and B enzymes. Studies in the future should be performed to investigate the antidepressant activity mechanism of these natural compounds. The current research could be an important step in the development of the new agents that can be used in the treatment of depression.
\end{abstract}

Keywords: antidepressant; forced swimming test; lamiaceae; Micromeria myrtifolia; monoamine oxidase; tail suspension test

\section{Introduction}

Depression is a widespread chronic psychiatric complaint which interferes with social life and work performance. Today, millions of people of all ages suffer from this disease [1]. According to figures from the World Health Organization, by the year 2020, depression is estimated to be the second known cause of world disability [2], and through 2030, it will probably make the greatest contribution to the burden of disease [3]. 
Depression is a mental disease associated with the interaction of psychological, social and biological factors. The development of this mood disorder can be triggered by several etiological factors, including personal and environmental conditions, genetic and biochemical parameters [4]. Differences in brain chemicals, low self-confidence personality, and stressful life conditions may contribute to the onset of depression. It is characterized by several symptoms such as the feeling of hopelessness or worthlessness; changes in appetite, weight and sleep patterns; fatigue; increased agitation and decreased interest in pleasurable stimuli. Actually, the most dangerous one is recurrent suicidal thoughts $[5,6]$. Depression can cause some damages to physical health. Depression-related physical illnesses such as diabetes, obesity [7], cardiovascular diseases [8], stroke, cancer, lung diseases [9] and loss of hearing and vision [10] show an enigmatic mind-body connection. The levels of monoamine neurotransmitters namely serotonin, noradrenaline, and dopamine; corticotrophin-releasing factor; corticotrophin-releasing hormone; cortisol and adrenocorticotropic hormone, and also the actions of hypothalamic-pituitary-adrenal (HPA) axis, adenylyl cyclase, and monoamine oxidase (MAO) are main biomarkers for diagnosis [11].

Medications available for the treatment of depression such as tricyclic antidepressants, monoamine oxidase inhibitors, selective serotonin reuptake inhibitors and specific serotonin-noradrenaline reuptake inhibitors [12]. However, the side profile effect profiles of above mentioned drugs regarding libido, sleep, body weight, and cardiovascular system because the treatment of depression is still not at the desired level [13-15]. The search for new alternatives to manage depression is turning scientists into natural resources especially phytochemicals. Large number of plants are traditionally used worldwide by indigenous people for the treatment of neurological health problems, and M. myrtifolia is only one of them [16].

Today, a large number of efficient treatment options are available for depression, but the reality is that no perfect solution exists that works quickly and is free of adverse reactions. Therefore, researchers are seeking alternatives to produce more specific, newer, safer, and cheaper medications nowadays and traditional medicinal plants provide an extensive research area for them. Considering traditional uses, thousands of promising plants for the future have not yet been studied in terms of medical potential. This is particularly important for diseases such as depression which have not yet reached the desired therapeutic level.

Micromeria is a large genus belongs to Lamiaceae family and widespread in Mediterranean regions. Flora of Turkey contains 14 Micromeria species (22 taxa), 12 of which are endemic [17]. Micromeria is used traditionally for ages in the cure of inflammation, fever, asthma, skin diseases, cardiac problems and digestive system disorders [18]. Dozens of studies have confirmed the biological activities of Micromeria species such as antifungal [19], antimicrobial [20], antioxidative [21], anticholinesterase [22], anti-inflammatory and gastroprotective [23], hepatoprotective [24], cytotoxic [25]. Phytochemical investigations on this genus have indicated the presence of several flavonoid compounds, saponins, tannins, anthraquinones and essential oils [26-30].

One of the Micromeria species, M. myrtifolia, a perennial suffruticose plant, has been used as pleasure and medicinal tea in Turkish traditional healing system for the treatment of gallstones and gastrointestinal disorders [16,17]. Moreover, the infusion prepared from the aerial parts of M. myrtifolia is used as relaxant and sedative by drinking one teacup 1-2 times a day [16,31]. The phytochemical screening of the volatile oil of M. myrtifolia indicated that it contained some bioactive constituents; monoterpene hydrocarbons ( $\alpha$ - and $\beta$-pinene, p-cymene, limonene etc.), oxygenated monoterpene derivatives (such as linalool, camphor, borneol), sesquiterpene hydrocarbons (germacrene D, $\beta$-caryophyllene, $\alpha$-humulene etc.), oxygenated sesquiterpenes (such as caryophyllene oxide), phenolic compounds (thymol, carvacrol, eugenol etc.), fatty acids and derivatives (such as pentadecanoic acid, hexadecanoic acid), carbonylic compounds (nonanal, decanal etc.), hydrocarbons and other types compounds ((Z)-Phytol) [32]. There are few studies on the biological activity of the plant $[32,33]$ and to date, no studies have been designed to investigate its antidepressant effect. 
Therefore, the aim of the present research is not only to demonstrate the antidepressant-like activity of M. myrtifolia in different experimental models of depression in mice, but also to reveal the responsible bioactive constituents of this relaxant ethnomedicinal plant.

\section{Results}

\subsection{Biological Activity Studies}

In the forced swimming test (FST), the inactivity seen in mice exhibits the behavioral despair seen in humans and conventional antidepressant drugs make a reduction in the duration of inactivity time [34]. If the animal displayed locomotor activity in stressful conditions, it was thought as a positive response for the avoiding of sedation. The results of FST were summarized in Table 1. The MeOH extract and Fractions B and C at the doses of $100 \mathrm{mg} / \mathrm{kg}$ shortened the immobility duration significantly with the values of $38.39 \%, 39.24 \%, 43.31 \%$, respectively. In addition, rosmarinic acid, myricetin, apigenin and naringenin at the doses of $25 \mathrm{mg} / \mathrm{kg}$ significantly decreased the immobility duration with the values of $37.59 \%, 38.41 \%, 31.13 \%$, and $28.80 \%$, respectively. Despite this, the EtOAc extract showed a noteworthy activity and the $n$-hexane extract did not exert antidepressant activity in this in vivo model.

Table 1. Effects of the extracts, fractions from $\mathrm{MeOH}$ extract and pure compounds from M. myrtifolia on the forced swimming test.

\begin{tabular}{|c|c|c|}
\hline Material & $\begin{array}{c}\text { Dose } \\
\text { (mg/kg p.o.) }\end{array}$ & $\begin{array}{c}\text { Duration of Immobility (s) } \\
\text { (Mean } \pm \text { S.E.M.) }\end{array}$ \\
\hline Control & - & $187.22 \pm 6.16$ \\
\hline$n$-Hexane extract & & $199.51 \pm 7.74$ \\
\hline EtOAc extract & 100 & $173.08 \pm 8.13$ \\
\hline $\mathrm{MeOH}$ extract & & $115.34 \pm 5.12 *$ \\
\hline \multirow{2}{*}{ Imipramine } & 30 & $109.61 \pm 4.23 * *$ \\
\hline & 50 & $94.26 \pm 4.01 * * *$ \\
\hline Control & - & $173.12 \pm 5.01$ \\
\hline Fr. A & & $192.31 \pm 3.96$ \\
\hline Fr. B & & $105.18 \pm 3.26^{* *}$ \\
\hline Fr. C & 100 & $98.15 \pm 2.07^{* * *}$ \\
\hline Fr. D & & $162.45 \pm 2.93$ \\
\hline Fr. E & & $181.26 \pm 4.12$ \\
\hline \multirow{2}{*}{ Imipramine } & 30 & $112.73 \pm 2.84^{* *}$ \\
\hline & 50 & $93.28 \pm 2.85^{* *}$ \\
\hline Control & - & $191.89 \pm 9.68$ \\
\hline Rosmarinic acid & & $119.76 \pm 6.49 * *$ \\
\hline Myricetin & 25 & $118.19 \pm 4.62 * *$ \\
\hline Apigenin & 25 & $132.15 \pm 7.06$ ** \\
\hline Naringenin & & $136.63 \pm 6.81 *$ \\
\hline \multirow{2}{*}{ Imipramine } & 30 & $128.00 \pm 5.19 * *$ \\
\hline & 50 & $97.02 \pm 3.74 * *$ \\
\hline
\end{tabular}

Similarly, TST is based on the observation of inactivity in stressful conditions [35]. Antidepressant drugs have the ability to decrease the duration of inactivity time in this experimental model [36]. As shown in Table 2, the immobility time in TST remarkably decreased after the treatment with the $\mathrm{MeOH}$ extract, similar to the reference medicament fluoxetine. The $\mathrm{MeOH}$ extract and Fraction $\mathrm{B}$ at the doses of $100 \mathrm{mg} / \mathrm{kg}$ shortened the immobility time significantly with the values of $35.24 \%, 36.69 \%$, respectively. Though rosmarinic acid significantly decreased immobility time with the value of $45.65 \%$, the other isolated compounds did not show any remarkable activity in TST model. 
Table 2. Effects of the extracts, fractions from $\mathrm{MeOH}$ extract and pure compounds from M. myrtifolia on the tail suspension test.

\begin{tabular}{ccc}
\hline Material & $\begin{array}{c}\text { Dose } \\
\text { (mg/kg p.o.) }\end{array}$ & $\begin{array}{c}\text { Duration of Immobility (s) } \\
\text { (Mean } \pm \text { S.E.M.) }\end{array}$ \\
\hline Control & - & $172.68 \pm 6.14$ \\
$n$-Hexane extract & 100 & $191.41 \pm 11.23$ \\
EtOAc extract & & $154.80 \pm 7.59$ \\
MeOH extract & 30 & $111.82 \pm 5.62^{*}$ \\
Imipramine & 50 & $105.41 \pm 3.62^{* *}$ \\
& - & $91.56 \pm 2.48^{* * *}$ \\
Control & & $195.75 \pm 10.63$ \\
Fr. A & 100 & $182.03 \pm 9.21$ \\
Fr. B & & $123.92 \pm 5.04^{*}$ \\
Fr. C & & $131.37 \pm 6.89$ \\
Fr. D & 30 & $184.91 \pm 10.17$ \\
Fr. E & 50 & $197.66 \pm 12.28$ \\
Imipramine & - & $108.82 \pm 4.90^{* *}$ \\
& & $95.42 \pm 3.20^{* * *}$ \\
\hline Control & 25 & $220.49 \pm 17.04$ \\
Rosmarinic acid & & $119.83 \pm 11.91 *$ \\
Myricetin & 30 & $176.17 \pm 15.26$ \\
Apigenin & 50 & $142.58 \pm 14.45$ \\
Naringenin & & $101.64 \pm 4.77^{* *}$ \\
Imipramine & & $84.90 \pm 2.49^{* * *}$ \\
\hline
\end{tabular}

${ }^{*} p<0.05 ;{ }^{* *} p<0.01 ;{ }^{* * *} p<0.001$; S.E.M.: Standard Error of Mean.

According to the monoamine hypothesis of depression, the mechanism of the pathophysiology of depression is the depletion of monoamine neurotransmitters, including serotonin, norepinephrine and/or dopamine in the central nervous system (CNS) [37]. Tetrabenazine, synthetic benzylquinolizine derivative [38], causes depletion of dopamine and other monoamines in the CNS and increases the risk of depressive disorders [39]. Similar results were received in the antagonism of ptosis and hypothermia induced by tetrabenazine test, as shown in Table 3. The MeOH extract antagonized hypothermia, ptosis, and motor depression in mice. However, the rest of the extracts did not show remarkable activity.

Table 3. Effects of the extracts, fractions from $\mathrm{MeOH}$ extract and pure compounds from M. myrtifolia on antagonism of tetrabenazine-induced ptosis and hypothermia.

\begin{tabular}{|c|c|c|c|}
\hline Material & $\begin{array}{c}\text { Dose } \\
\text { (mg/kg p.o.) }\end{array}$ & $\begin{array}{c}\text { Ptosis Mean Score } \\
(30 \mathrm{~min})(\text { Mean } \pm \text { S.E.M.) }\end{array}$ & $\begin{array}{c}\text { Mean Decrease in Rectal Temperature }\left({ }^{\circ} \mathrm{C}\right) \\
\text { (Mean } \pm \text { S.E.M.) }\end{array}$ \\
\hline Control & - & $3.19 \pm 0.63$ & $4.88 \pm 0.32$ \\
\hline$n$-Hexane extract & & $3.24 \pm 0.52$ & $4.91 \pm 0.74$ \\
\hline EtOAc extract & 100 & $2.71 \pm 0.49$ & $4.07 \pm 0.52$ \\
\hline $\mathrm{MeOH}$ extract & & $2.13 \pm 0.21 *$ & $2.46 \pm 0.21 *$ \\
\hline Fluoxetine & 25 & $0.00 \pm 0.00^{* * *}$ & $0.43 \pm 0.17^{* *}$ \\
\hline Control & - & $4.16 \pm 0.92$ & $5.93 \pm 0.48$ \\
\hline Fr. A & & $3.96 \pm 0.38$ & $4.82 \pm 0.54$ \\
\hline Fr. B & & $2.34 \pm 0.21 *$ & $2.82 \pm 0.10^{*}$ \\
\hline Fr. C & 100 & $2.91 \pm 0.18^{*}$ & $3.06 \pm 0.27 *$ \\
\hline Fr. D & & $4.29 \pm 0.63$ & $5.11 \pm 0.82$ \\
\hline Fr. E & & $4.57 \pm 0.51$ & $6.12 \pm 0.43$ \\
\hline Fluoxetine & 25 & $0.00 \pm 0.00^{* * *}$ & $0.49 \pm 0.11^{* * *}$ \\
\hline Control & - & $3.95 \pm 0.83$ & $6.18 \pm 1.07$ \\
\hline Rosmarinic acid & & $2.18 \pm 0.66^{*}$ & $3.11 \pm 0.74 *$ \\
\hline Myricetin & & $2.53 \pm 0.48^{*}$ & $2.49 \pm 0.42 *$ \\
\hline Apigenin & 25 & $2.31 \pm 0.45^{*}$ & $2.62 \pm 0.58 *$ \\
\hline Naringenin & & $3.22 \pm 0.94$ & $3.34 \pm 0.87$ \\
\hline Fluoxetine & & $0.00 \pm 0.00^{* * *}$ & $0.36 \pm 0.15^{* * *}$ \\
\hline
\end{tabular}

${ }^{*} p<0.05 ;{ }^{* *} p<0.01 ;{ }^{* * *} p<0.001$; S.E.M.: Standard Error of Mean. 
The MAO inhibition assay is a practical and speed test for assessing the inhibition of MAO enzyme, which is known to play an active role in the pathogenesis of depression [33]. In MAO inhibition assay, the $\mathrm{MeOH}$ extract inhibited MAO-A and MAO-B enzymes with the $\mathrm{IC}_{50}$ values of 4.7 and 1.4, respectively (Table 4 ).

Table 4. Effects of the extracts, fractions from $\mathrm{MeOH}$ extract and pure compounds from M. myrtifolia on the MAO inhibition assay.

\begin{tabular}{ccc}
\hline \multirow{2}{*}{ Material } & \multicolumn{2}{c}{ IC $_{\mathbf{5 0}}(\mathrm{mg} / \mathbf{m L})$} \\
\cline { 2 - 3 } & MAO-A & MAO-B \\
\hline Control & $>10$ & $>10$ \\
n-Hexane extract & $>10$ & 7.3 \\
EtOAc extract & $>10$ & 8.9 \\
MeOH extract & 4.7 & 1.4 \\
Fr. A & $>10$ & $>10$ \\
Fr. B & 5.9 & 4.8 \\
Fr. C & 4.1 & 2.2 \\
Fr. D & $>10$ & $>10$ \\
Fr. E & $>10$ & $>10$ \\
Rosmarinic acid & 6.5 & 5.3 \\
Myricetin & 4.4 & 2.7 \\
Apigenin & 3.1 & 1.6 \\
Naringenin & 5.9 & 1.9 \\
Caffeine & 0.2 & 0.5 \\
\hline
\end{tabular}

The MeOH extract was subjected to RP-18 column chromatography to isolate the constituents responsible for the antidepressant activity, and the eluted fractions were grouped into five categories based on their chemical fingerprinting on TLC examination. In the in vivo and in vitro activity studies, Fraction B and C showed a significant activity (Tables 1-4).

Thus, Fractions B and C were further fractionated using Sephadex LH-20 and silica jel column. Further, rosmarinic acid (1) from Fraction B and myricetin (2), apigenin (3) and naringenin (4) from Fraction $\mathrm{C}$ were isolated and were identified using spectral analysis (Figure 1).<smiles>O=C(/C=C/c1ccc(O)c(O)c1)O[C@@H](Cc1ccc(O)c(O)c1)C(=O)O</smiles>

(1)<smiles>O=c1cc(-c2ccc(O)cc2)oc2cc(O)cc(O)c12</smiles>

(3)<smiles>O=c1c(O)c(-c2cc(O)c(O)c(O)c2)oc2cc(O)cc(O)c12</smiles>

(2)<smiles>O=C1CC(c2ccc(O)cc2)Oc2cc(O)cc(O)c21</smiles>

(4)

Figure 1. Chemical structures of rosmarinic acid (1), myricetin (2), apigenin (3), and naringenin (4) isolated from Micromeria myrtifolia. 
In further studies, isolated compounds were purchased and their antidepressant activities were evaluated. According to the results, rosmarinic acid, myricetin, apigenin, and naringenin showed statistically significant activity on the forced swimming test and tetrabenazine-induced ptosis models, whereas only rosmarinic acid showed statistically significant activity on the tail suspension test (Table 2). Fractions B and C significantly inhibited MAO A and B enzymes. Apigenin isolated from Fraction C displayed the highest inhibitory activity on both enzymes.

\subsection{NMR Data of Isolated Compounds}

Rosmarinic acid (1): ESI-MS m/z: 361.0914. ${ }^{1} \mathrm{H}-\mathrm{NMR}\left(500 \mathrm{MHz}, \mathrm{CD}_{3} \mathrm{OD}\right): \delta 7.48(1 \mathrm{H}, \mathrm{d}, J=15.2 \mathrm{~Hz}$, H-7'), $7.00\left(1 \mathrm{H}, \mathrm{d}, J=1.8 \mathrm{~Hz}, \mathrm{H}-2^{\prime}\right), 6.88\left(1 \mathrm{H}, \mathrm{dd}, J=8.0 / 1.8 \mathrm{~Hz}, \mathrm{H}-6^{\prime}\right), 6.71\left(1 \mathrm{H}, \mathrm{d}, J=8.0 \mathrm{~Hz}, \mathrm{H}-5^{\prime}\right)$, $6.21\left(1 \mathrm{H}, \mathrm{d}, J=15.2 \mathrm{~Hz}, \mathrm{H}-8^{\prime}\right), 6.71(1 \mathrm{H}, \mathrm{d}, J=1.8 \mathrm{~Hz}, \mathrm{H}-2), 6.61(1 \mathrm{H}, \mathrm{d}, J=8.0 \mathrm{~Hz}, \mathrm{H}-5), 6.59(1 \mathrm{H}, \mathrm{dd}$, $J=8.0 / 1.8 \mathrm{~Hz}, \mathrm{H}-6), 5.03(1 \mathrm{H}, \mathrm{dd}, J=9.1 / 3.5 \mathrm{~Hz}, \mathrm{H}-8), 3.01(1 \mathrm{H}, \mathrm{dd}, J=14.0 / 3.5 \mathrm{~Hz}, \mathrm{H}-7 \mathrm{~b}), 2.90(1 \mathrm{H}, \mathrm{dd}$, $J=14.0 / 9.1 \mathrm{~Hz}, \mathrm{H}-7 \mathrm{a}) ;{ }^{13} \mathrm{C}-\mathrm{NMR}\left(125 \mathrm{MHz}, \mathrm{CD}_{3} \mathrm{OD}\right): \delta 168.2\left(\mathrm{C}-9^{\prime}\right), 149.5\left(\mathrm{C}-4^{\prime}\right), 147.3\left(\mathrm{C}-7^{\prime}\right), 146.7$ $\left(\mathrm{C}-3^{\prime}\right), 127.1\left(\mathrm{C}-1^{\prime}\right), 122.6\left(\mathrm{C}-6^{\prime}\right), 116.1\left(\mathrm{C}-5^{\prime}\right), 114.8\left(\mathrm{C}-8^{\prime}\right), 113.8\left(\mathrm{C}-2^{\prime}\right), 167.0(\mathrm{C}-9), 145.7$ (C-3), 144.8 (C-4), 129.3 (C-1), 121.3 (C-6), 117.1 (C-2), 116.0 (C-5), 76.0 (C-8), 37.3 (C-7).

Myricetin (2): ESI-MS m/z: 319.0448. ${ }^{1} \mathrm{H}-\mathrm{NMR}\left(500 \mathrm{MHz}, \mathrm{CD}_{3} \mathrm{OD}\right): \delta 7.21\left(2 \mathrm{H}, \mathrm{s}, \mathrm{H}-2^{\prime} / 6^{\prime}\right), 6.35$ (1H, d, $J=1.8 \mathrm{~Hz}, \mathrm{H}-8), 6.13(1 \mathrm{H}, \mathrm{d}, J=1.8 \mathrm{~Hz}, \mathrm{H}-6) ;{ }^{13} \mathrm{C}-\mathrm{NMR}\left(125 \mathrm{MHz}, \mathrm{CD}_{3} \mathrm{OD}\right): \delta 173.1(\mathrm{C}-4), 163.8(\mathrm{C}-7)$, 160.5 (C-5), 155.6 (C-9), 146.3 (C-2), $145.3\left(\mathrm{C}-3^{\prime} / 5^{\prime}\right), 135.4(\mathrm{C}-3), 135.3\left(\mathrm{C}-4^{\prime}\right), 120.5\left(\mathrm{C}-1^{\prime}\right), 106.1\left(\mathrm{C}-2^{\prime} / 6^{\prime}\right)$, 104.6 (C-10), 97.7 (C-6), 92.9 (C-8).

Apigenin (3): ESI-MS m/z: 271.0596. ${ }^{1} \mathrm{H}-\mathrm{NMR}\left(500 \mathrm{MHz}, \mathrm{CD}_{3} \mathrm{OD}\right): \delta 7.88\left(2 \mathrm{H}, \mathrm{d}, J=8.8 \mathrm{~Hz}, \mathrm{H}-2^{\prime} / 6^{\prime}\right)$, $6.91\left(2 \mathrm{H}, J=8.8 \mathrm{~Hz}, \mathrm{H}-3^{\prime} / 5^{\prime}\right), 6.73(1 \mathrm{H}, \mathrm{s}, \mathrm{H}-3), 6.42(1 \mathrm{H}, \mathrm{d}, J=2.0 \mathrm{~Hz}, \mathrm{H}-8), 6.11(1 \mathrm{H}, \mathrm{d}, J=2.0 \mathrm{~Hz}, \mathrm{H}-6)$; ${ }^{13} \mathrm{C}-\mathrm{NMR}\left(125 \mathrm{MHz}, \mathrm{CD}_{3} \mathrm{OD}\right): \delta 183.7$ (C-4), 166.3 (C-7), 165.8 (C-2), 163.2 (C-5), $163.1\left(\mathrm{C}-4^{\prime}\right), 158.8$ (C-9), $131.3\left(\mathrm{C}-2^{\prime} / 6^{\prime}\right), 123.2\left(\mathrm{C}-1^{\prime}\right), 116.0\left(\mathrm{C}-3^{\prime} / 5^{\prime}\right), 105.1(\mathrm{C}-10), 103.9(\mathrm{C}-3), 100.1(\mathrm{C}-6), 94.6(\mathrm{C}-8)$.

Naringenin (4): ESI-MS m/z: $273.0752{ }^{1} \mathrm{H}-\mathrm{NMR}\left(500 \mathrm{MHz}, \mathrm{CD}_{3} \mathrm{OD}\right): \delta 7.34\left(2 \mathrm{H}, \mathrm{d}, J=8.8 \mathrm{~Hz}, \mathrm{H}-2^{\prime} / 6^{\prime}\right)$, $6.87\left(2 \mathrm{H}, \mathrm{d}, J=8.8 \mathrm{~Hz}, \mathrm{H}-3^{\prime} / 5^{\prime}\right), 5.92(1 \mathrm{H}, \mathrm{d}, J=2.2 \mathrm{~Hz}, \mathrm{H}-6), 5.90(1 \mathrm{H}, \mathrm{d}, J=2.2 \mathrm{~Hz}, \mathrm{H}-8), 5.31(1 \mathrm{H}$, $\mathrm{dd}, J=13.1 / 2.8 \mathrm{~Hz}, \mathrm{H}-2), 3.11(1 \mathrm{H}, \mathrm{dd}, J=17.8 / 13.1 \mathrm{~Hz}, \mathrm{H}-3 \mathrm{a}), 2.68(1 \mathrm{H}, \mathrm{dd}, J=17.8 / 2.8 \mathrm{~Hz}, \mathrm{H}-3 \mathrm{~b})$; ${ }^{13} \mathrm{C}-\mathrm{NMR}\left(125 \mathrm{MHz}, \mathrm{CD}_{3} \mathrm{OD}\right): \delta 197.3$ (C-4), 168.1 (C-9), 165.8 (C-5), 164.5 (C-7), 158.1 (C-4'), 129.5 $\left(\mathrm{C}-1^{\prime}\right), 128.4\left(\mathrm{C}-2^{\prime} / 6^{\prime}\right), 115.6\left(\mathrm{C}-3^{\prime} / 5^{\prime}\right), 101.8(\mathrm{C}-10), 97.3(\mathrm{C}-6), 96.9(\mathrm{C}-8), 78.5(\mathrm{C}-2), 42.2(\mathrm{C}-3)$.

\section{Discussion}

Until now, the antidepressant activity of many phytochemical compounds has been investigated. The phenolic compounds, which are among these phytochemicals, were divided into several sub-groups, including phenolic acids, flavonoids, chromones, coumarins, anthraquinones, stilbenes and lignans, based on the changes in their chemical structures [40]. Polyphenols with potent antioxidant properties are suggested for the treatment of different conditions, including degenerative, cardiovascular and gastrointestinal disorders [40,41]. Flavonoid type compounds are generally known for their hepatoprotective, antioxidant, antibacterial, anti-inflammatory and antiviral activities [42,43]. They are also widely studied phytochemicals in terms of their antidepressant activities and mechanisms. The mechanisms at this point could be gene regulation for neurotransmitter receptor expression and reversal of monoamine neurotransmitter attenuations by norepinephrine (NE), dopamine (DA), serotonin (5-HT), and 5-Hydroxyindoleacetic acid (5-HIAA) [44-48]. For example, baicalein exerted antidepressant-like activity by increasing extracellular signal-regulated kinase (ERK) phosphorylation and brain-derived neurotrophic factor (BDNF) [49]; baicalin by decreasing MAO-A and B activity [50]; hesperidin by effecting 5-HT receptors and $\mathrm{k}$-opioid [51]; quercetin by showing neuroprotective effect through microglial inhibitory pathway [52]; rutin and quercitrin by increasing mRNA expression of pro-opiomelanocortin (a precursor of several types of peptides that seems to be dysregulated in depression) and elevating 5 -HT and NE availability in synaptic cleft $[53,54]$.

Plenty of studies have been designed to assess the antidepressant-like activity of apigenin so far. Nakazawa et al. (2003) reported that apigenin, which is a plant-derived flavonoid abundant in fruits of 
Citrus, possessed antidepressant-like effect in mice and decreased the duration of immobility at the acute doses of 12.5 and $25 \mathrm{mg} / \mathrm{kg}$ (i.p.) preventing the stress-induced changes in dopamine turnover in hypothalamus [55]. However, Yi et al. found that acute oral treatment with apigenin did not show any antidepressant-like activity in mice. For this reason, they also tried subchronic and chronic treatment and reported that a two-week oral apigenin treatment at the daily doses of 10 and $20 \mathrm{mg} / \mathrm{kg}$ exerted significant antidepressant activity in mice by downregulation of the cAMP pathway and normalization of the central monoamine neurotransmitter systems and HPA axis alterations [56]. Li et al. investigated the antidepressant-like activity of chronic intraperitoneal administration of apigenin and found that it reversed the depressive-like behavior induced by tumor necrosis factor- $\alpha$ (TNF- $\alpha$ ) without altering locomotor activity at a dose of $50 \mathrm{mg} / \mathrm{kg}$ [57]. As reported by Weng et al., the oral apigenin treatment at the doses of 20 and $40 \mathrm{mg} / \mathrm{kg}$ for 21 days possessed significant antidepressant activity in chronic corticosteroid-treated mice by up-regulation of BDNF levels in the hippocampus [58]. Myricetin is one of the well-known flavonols investigated for antidepressant activity. Ma et al. revealed that chronic administration of myricetin at the dosage of $50 \mathrm{mg} / \mathrm{kg}$ showed antidepressant effect improving the activity of glutathione peroxidase (GSH-PX) in the hippocampus, and normalizing of the decreased brain-derived neurotrophic factor (BDNF) levels in mice exposed to repeated stress [59]. Several previous studies verified the antidepressant activity of naringenin, which is a dietary a flavanone widely found in peels of citrus fruits, in behavioral models of depression. Yi et al. evaluated neuropharmacological mechanism of naringenin and concluded that naringenin possessed potent antidepressant-like property through neuroprotective and monoamine oxidase inhibitory activities at the doses of 10,20 , and $50 \mathrm{mg} / \mathrm{kg}$ in mice [60]. Yi et al. attributed the antidepressant activity of naringenin to elevate the 5-HT, NE, and BDNF levels as well as glucocorticoid receptors [60-62]. Recent publications demonstrated that rosmarinic acid is one of the polyphenolic compounds endowed with antidepressant-like effect. Ito et al. attributed the activity of rosmarinic acid $(1.0,2.0,4.0 \mathrm{mg} / \mathrm{kg} / \mathrm{bw}$, i.p.) promotion of neurogenesis in hippocampus of mice [63]. Jin et al. proved that rosmarinic acid administration (daily 5 and $10 \mathrm{mg} / \mathrm{kg}$, for 14 days) showed activity in rats via increasing astrocytic BDNF expression in the hippocampus through modulation of the extracellular-regulated kinase phosphorylation [64]. Kondo et al. suggested that rosmarinic acid (5 and $10 \mathrm{mg} / \mathrm{kg} / \mathrm{day}$, for 7 days) exerted antidepressant activity in mice via modulation of dopamine and corticosterone, through the upregulation of tyrosine hydroxylase (TH) gene expression in the animals' brains [65].

Petersen and Simmonds (2003) reported that rosmarinic acid showed a very low toxicity with a LD50 in mice of $561 \mathrm{mg} / \mathrm{kg}$ after intravenous application [66]. Semwal et al. (2016) exhibited that intraperitoneal administration of myricetin at a dose of $1000 \mathrm{mg} / \mathrm{kg}$ to mice did not reveal any toxic effects or fatalities. The compound did not cause any toxicity at doses above $100 \mathrm{mg} / \mathrm{kg}$ (LD50 value) in zebrafish larvae induced by UVB-generated ROS [67]. Osigwe et al. (2017) reported to possess apigenin very low toxicity [68].

The present study exerted that the MeOH extract of M. myrtifolia and its phenolic compounds showed remarkable in vivo and in vitro antidepressant activities. In the discovery of better agents against depression, this work is a step and further studies should be conducted for the determination of the mechanism.

\section{Materials and Methods}

\subsection{Plant Material}

Fresh aerial parts of M. myrtifolia were collected from Çıral1-Antalya, Turkey, in April 2016. The voucher sample (GUEF 3487) was deposited at the Herbarium of the Faculty of Pharmacy, Gazi University, Ankara, Turkey. The botanical identification of the plant was realized by Prof. Dr. Hayri DUMAN of Gazi University, Department of Biology, Faculty of Science and Art, Ankara. 


\subsection{Extraction, Fractionation, and Isolation Process}

The dried and ground plant materials were subjected to maceration using $n$-hexane, ethyl acetate (EtOAc), and methanol $(\mathrm{MeOH})$ as solvents, respectively at room temperature. Following the filtration process, the prepared extracts were evaporated to dryness through rotary evaporator. The percentage yield of the methanolic extract $(17.13 \%)$ was higher than $n$-hexane $(9.05 \%)$ and EtOAc $(6.24 \%)$ extracts.

\subsubsection{Fractionation of $\mathrm{MeOH}$ Extract}

$\mathrm{MeOH}$ extract of the aerial parts (25 g) was subjected to RP-18 column vacuum liquid chromatography 2 L H2O, 1 L H2O:MeOH (90:10), 1 L H2O:MeOH (80:20), 2 L H2O:MeOH (70:30), 2 L H2O:MeOH (60:40), 2 L H2O:MeOH (50:50), 2 L H2O:MeOH (40:60), 2 L H2O:MeOH (30:70), $2 \mathrm{~L} \mathrm{H} 2 \mathrm{O}: \mathrm{MeOH}$ (20:80), $1 \mathrm{~L} \mathrm{H} 2 \mathrm{O}: \mathrm{MeOH}$ (10:90), $1 \mathrm{~L} \mathrm{MeOH}$, and $1 \mathrm{~L}$ acetone] to obtain 30 fractions, which were combined as follows after thin-layer chromatography (TLC) control using EtOAc:CHCl3:MeOH:H2O (6:4:4:1) as the mobile phase: Fractions A-E. These five different types fractions were tested for antidepressant-like activity using several in vivo model. The results showed that Fraction $B$ and $C$ were more active from others, and then these fractions were chromatographed over Sephadex LH-20 column to obtain pure compounds.

\subsubsection{Determination of the Structure of Compounds}

Nuclear magnetic resonance $\left({ }^{1} \mathrm{H}\right.$ - and $\left.{ }^{13} \mathrm{C}-\mathrm{NMR}\right)$ and mass spectroscopy (MS) techniques were used for the structural elucidation of the compounds. NMR spectra were recorded on a Bruker spectrometer (400 MHz for ${ }^{1} \mathrm{H}-\mathrm{NMR}$ and $100 \mathrm{MHz}$ for ${ }^{13} \mathrm{C}-\mathrm{NMR}$ ) instrument and using $\mathrm{CD}_{3} \mathrm{OD}$ as the solvent. ESI-MS analyses were performed using a spectrometer (Waters LCT Premier XE UPLC/TOF-MS, Santa Clara, CA, USA). The isolates were identified as rosmarinic acid (1), myricetin (2), apigenin (3), and naringenin (4) by assessing and comparing their spectroscopic data with those published in related references.

\subsection{Biological Activity Tests}

\subsubsection{Animals}

The experiments were conducted on male mice of BALB/c strain (25-30 g) for the in vivo behavioural experiments and Sprague-Dawley male rats (180-200 g) were used for the MAO inhibitory activity tests. All animals were provided from Kobay Test Animals Laboratory (Ankara, Turkey) and kept in $12 \mathrm{~h}$ light/dark cycle at room conditions with free access to laboratory food and water tap ad libitum for three days before the pharmacological experiments. All of the experiments were performed according to the international guidelines on animal experiments and biodiversity rights. Seven mice were used for each experimental group. All the studies were performed conferring to the international rules regarding the animal experiments and biodiversity rights (Kobay Ethical Council Project Number: 255).

\subsubsection{Preparation of Test Samples for Bioassay}

All of the extracts were administered at the dose of $100 \mathrm{mg} / \mathrm{kg}$ in $0.5 \%$ aqueous carboxymethyl cellulose $(\mathrm{CMC})$ suspension. The mice in the control group were treated with only $0.5 \% \mathrm{CMC}$ suspension (vehicle) under the same conditions. Tricyclic antidepressant imipramin at the dosages of 30 and $50 \mathrm{mg} / \mathrm{kg}$ (Merck) and fluoxetine at the dosage of $25 \mathrm{mg} / \mathrm{kg}$ (Merck) in 0.5\% CMC were used as reference medicaments.

\subsubsection{Forced Swimming Test (Behavioral Despair Test)}

Antidepressant-like activity of each test samples were assessed in the forced swimming test (FST) based on the methodology described by Porsolt et al. [33] with minor modifications. One hour after 
the oral application of the test samples/reference medicaments, the animals were individually placed in a $20 \mathrm{~cm}$ high transparent glass beaker filled with tap water at $23 \pm 2{ }^{\circ} \mathrm{C}$ to a height of $10 \mathrm{~cm}$ and forced to swim. The water was refreshed after each experiment and each mouse was used just once. All of the experiments were videotaped, and the total duration of inactivity (s) was chronometered the last $2 \mathrm{~min}$ of the $6 \mathrm{~min}$-long period. Animals were accepted inactive when they did not try to escape, except for movements necessary to hold their heads in the water. Five different experimental groups were formed for the evaluation of the effect of each extract and seven experimental groups were used to assess the potential of the fractions [69].

\subsubsection{Tail Suspension Test}

The tail suspension test (TST) was performed as described by Steru et al. [70]. One hour after the application of the test materials/reference medicament orally, the mice were individually suspended $50 \mathrm{~cm}$ above the floor approximately by $1 \mathrm{~cm}$ from the tip of the tail with an adhesive tape. All of the experiments were videotaped, and the total duration of inactivity (s) was scored for the last 6 min of the 10 min-long sessions. Immobility was measured when the mice did not make any struggle to get rid of the tape for at least $1 \mathrm{~min}$. Four different experimental groups were formed for the evaluation of the effect of each extract and six experimental groups were used to assess the activity of the fractions [69].

\subsubsection{Antagonism of Hypothermia and Ptosis Induced by Tetrabenazine}

The mice whose rectal temperatures were measured as $36-38^{\circ} \mathrm{C}$ received each test sample/reference drug orally $60 \mathrm{~min}$ before the tetrabenazine injection $(32 \mathrm{mg} / \mathrm{kg})$ intraperitoneally which was dissolved in $0.1 \mathrm{M}$ tartaric acid ( $\mathrm{pH}$ changed to 6 using $\mathrm{NaOH} \mathrm{10 \% ).} \mathrm{After} 30 \mathrm{~min}$, the mice were put at the center of a disk (diameter of $20 \mathrm{~cm}$ ) and the degree of palpebral ptosis and the akinesia exhibited by each mouse was assessed within $10 \mathrm{~s}$. The ptosis degree was rated in accordance with the following rating scale: 0 for eyes open; 1 for one-quarter closed; 2 for half closed; 3 for three-quarters closed; and 4 for completely closed [36]. The mice were not accepted akinetic if they gave at least one of the following responses: Walking to the edge of the disk and looking over the side, moving $180^{\circ}$ in place, $90^{\circ}$ head movement followed by a $45^{\circ}$ movement in the opposite direction [34]. If the animal had locomotor activity, sedation was thought to be prevented. The number of mice exhibiting a positive comeback was divided by the number of animals in the group and multiplied by 100 to obtain the percentage of animals exhibiting locomotor activity at the indicated dose. The rectal temperature of each mouse was measured with a thermometer 60 min after the injection of tetrabenazine and the temperature changes were calculated. Four different experimental groups were formed for the evaluation the effect of each extract and six experimental groups were used to assess the activity of the fractions [69].

\subsubsection{The Inhibitory Activity on the MAO A\&B}

The effect of extracts, fractions and isolated compounds from $\mathrm{MeOH}$ extract on the activity of MAO A and B were investigated in vitro in the brain and liver of the rats. Enzyme sources were prepared according to the method of Hwang (2003) [71] from brain of Sprague-Dawley male rats. The anesthetized rats lost blood with $3.13 \%$ sodium citrated syringe from the heart. The brain tissue was obtained from the decapitated brain which was washed with $0.01 \mathrm{M}$ phosphate buffered saline (PBS, pH 7.0), and homogenate at $40^{\circ} \mathrm{C}$ for $1 \mathrm{~min}$ followed by adding cold $0.25 \mathrm{mM}$ sucrose by nine parts of wet weight of tissue. Centrifuged at $700 \mathrm{~g}$ in $40{ }^{\circ} \mathrm{C}$ for $20 \mathrm{~min}$. Supernatant was centrifuged at 18,000 g for 20 min immediately. Pellet was suspended in five parts of PBS, and used for crude enzyme preparation. Prepared crude MAO-A $(0.5 \mathrm{~mL})$ was added to test tubes with $1.0 \mathrm{~mL}$ of test materials. It was incubated in shaking incubator at $37.5^{\circ} \mathrm{C}$ for $15 \mathrm{~min}$. As a substrate, $0.5 \mathrm{~mL}$ of $1.0 \mathrm{mM}$ serotonin was added and incubated at $37.5^{\circ} \mathrm{C}$ for $90 \mathrm{~min}$. To terminate the enzyme action, test tubes were heated at $95^{\circ} \mathrm{C}$ water bath for $3 \mathrm{~min}$. and centrifuged at $700 \mathrm{~g}$ for $20 \mathrm{~min}$. immediately. Supernatants were poured in prepared Amberlite CG-50 $(\mathrm{H}+$ form $)$ column $(0.6 \times 4 \mathrm{~cm})$. After washing with distilled water thoroughly (over $40 \mathrm{~mL}$ ), eluted with $3 \mathrm{~mL}$ of $4 \mathrm{~N}$ acetic acid, elute was determined of absorbance 
at $277 \mathrm{~nm}$. Instead of samples, the same volumes of distilled water were added in the control. In the sample controls, the substrates were added on the time of activity termination instead of initiation of action. Each group was performed in duplicate and calculated for the inhibition percentages of samples by proper expression.

Author Contributions: F.T.G.D. and M.I. performed in vivo, in vitro and isolation studies. E.K.A. designed the experiment, analyzed the data and wrote the manuscript.

Funding: APC was sponsored by MDPI.

Conflicts of Interest: The authors declare no conflict of interest.

\section{References}

1. Mental Health. Available online: https://www.who.int/mental_health/world-mental-health-day/2017/en/ (accessed on 8 April 2019).

2. Burden of Mental and Behavioural Disorders. Available online: https://www.who.int/whr/2001/chapter2/en/ index4.html (accessed on 8 April 2019).

3. The Global Burden of Disease 2004 Update. Available online: http://www.who.int/healthinfo/global_burden_ disease/GBD_report_2004update_full.pdf (accessed on 16 June 2012).

4. Kashani, J.H.; Barbero, G.J.; Bolander, F.D. Depression in hospitalized pediatric patients. J. Am. Acad. Child Psychiatry 1981, 20, 123-134. [CrossRef]

5. Ohayon, M.M. Specific characteristics of the pain/depression association in the general population. J. Clin. Psychiatry 2004, 65, 5-9.

6. Zuckerman, B.; Amaro, H.; Bauchner, H.; Cabral, H. Depressive symptoms during pregnancy-Relationship to poor health behaviors. Am. J. Obstet. Gynecol. 1989, 160, 1107-1111. [CrossRef]

7. Sevilla-Gonzalez, M.D.; Quintana-Mendoza, B.M.; Aguilar-Salinas, C.A. Interaction between depression, obesity, and type 2 diabetes: A complex picture. Arch. Med. Res. 2017, 48, 582-591. [CrossRef]

8. Goodwin, G.M. Depression and associated physical diseases and symptoms. Dialogues Clin. Neurosci. 2006, 8, 259. [PubMed]

9. Bisschop, M.I.; Knegsman, D.M.W.; Beekman, A.T.F.; Deeg, D.J.H. Chronic diseases and depression: The modifying role of psychosocial resources. Soc. Sci. Med. 2004, 59, 721-733. [CrossRef]

10. Huang, C.Q.; Dong, B.R.; Lu, Z.C.; Yue, J.R.; Liu, Q.X. Chronic diseases and risk for depression in old age: A meta-analysis of published literature. Ageing Res. Rev. 2010, 9, 131-141. [CrossRef] [PubMed]

11. Rabiei, Z.; Rabiei, S. A review on antidepressant effect of medicinal plants. Bangladesh J. Pharmacol. 2017, 12, 1-11. [CrossRef]

12. Antai-Otong, D. Antidepressant-induced insomnia: Treatment options. Perspect. Psychiatr. Care 2004, 40, 29-33. [CrossRef]

13. Baldwin, D.; Mayers, A. Sexual side-effects of antidepressant and antipsychotic drugs. Adv. Psychiatr. Treat. 2003, 9, 202-210. [CrossRef]

14. Park, J.S.; Grow, J.M. The social reality of depression: DTC advertising of antidepressants and perceptions of the prevalence and lifetime risk of depression. J. Bus. Ethics 2008, 79, 379-393. [CrossRef]

15. Redrobe, J.P.; Bourin, M. Augmentation of antidepressant pharmacotherapy: A preclinical approach using the mouse forced swimming test. CNS Spectrum 1999, 4, 73-81. [CrossRef]

16. Sargin, S.A. Ethnobotanical survey of medicinal plants in Bozyazi district of Mersin, Turkey. J. Ethnopharmacol. 2015, 173, 105-126. [CrossRef] [PubMed]

17. Davis, P.H. Micromeria Benth. In Flora of Turkey and the East Aegean Islands; Davis, P.H., Ed.; Edinburgh University Press: Edinburgh, UK, 1982; Volume 7, pp. 329-331.

18. Said, O.; Khalil, K.; Fulder, S.; Azaizeh, H. Ethnopharmacological survey of medicinal herbs in Israel, the Golan Heights and the West Bank region. J. Ethnopharmacol. 2002, 83, 251-265. [CrossRef]

19. El-Seedi, H.R.; Khattab, A.; Gaara, A.H.M.; Mohamed, T.K.; Hassan, N.A.; El-Kattan, A.E. Essential oil analysis of Micromeria nubigena HBK and its antimicrobial activity. J. Essent. Oil Res. 2008, 20, 452-456. [CrossRef]

20. Duru, M.E.; Ozturk, M.; Ugur, A.; Ceylan, O. The constituents of essential oil and in vitro antimicrobial activity of Micromeria cilicica from Turkey. J. Ethnopharmacol. 2004, 94, 43-48. [CrossRef] [PubMed] 
21. Vladimir-Knezevic, S.; Blazekovic, B.; Stefan, M.B.; Alegro, A.; Koszegi, T.; Petrik, J. Antioxidant activities and polyphenolic contents of three selected Micromeria species from Croatia. Molecules 2011, 16, 1454-1470. [CrossRef]

22. Ozturk, M.; Kolak, U.; Duru, M.E.; Harmandar, M. GC-MS analysis of the antioxidant active fractions of Micromeria juliana with anticholinesterase activity. Nat. Prod. Commun. 2009, 4, 1271-1276.

23. Abu-Gharbieh, E.; Shehab, N.G.; Khan, S.A. Anti-inflammatory and gastroprotective activities of the aqueous extract of Micromeria fruticosa (L.) Druce ssp serpyllifolia in mice. Pak. J. Pharm. Sci. 2013, 26, 799-803.

24. Abu-Gharbieh, E.; Ahmed, N.G. Bioactive content, hepatoprotective and antioxidant activities of whole plant extract of Micromeria fruticosa (L) Druce ssp. serpyllifolia F Lamiaceae against carbon tetrachloride-induced hepatotoxicity in mice. Trop. J. Pharm. Res. 2016, 15, 2099-2106. [CrossRef]

25. Koc, K.; Ozdemir, O.; Kizilkaya, O.F.; Sengul, M.; Turkez, H. Cytotoxic activity of the aqueous extract of Micromeria fruticosa (L.) Druce subsp serpyllifolia on human U-87 MG cell lines. Arch. Biol. Sci. 2017, 69, 449-453. [CrossRef]

26. Ambreen, M.; Ahmad, M. Phytochemical analysis of selected medicinal plants used for dermatological infections. Sci. Int. (Lahore) 2016, 28, 4207-4210.

27. Marin, P.D.; Grayer, R.J.; Veitch, N.C.; Kite, G.C.; Harborne, J.B. Acacetin glycosides as taxonomic markers in Calamintha and Micromeria. Phytochemistry 2001, 58, 943-947. [CrossRef]

28. Nikolova, M.; Aneva, I.; Zhelev, P.; Dimitrova, M. Flavonoid compounds and antioxidant activity of Bulgarian species of Micromeria. In Proceedings of the Youth Scientific Conference "Kliment's Days", Sofia, Bulgaria, 17 November 2017.

29. Tomasbarberan, F.A.; Gil, M.I.; Marin, P.D.; Tomaslorente, F. Flavonoids from some Yugoslavian Micromeria Species-Chemotaxonomical aspects. Biochem. Syst. Ecol. 1991, 19, 697-698. [CrossRef]

30. Vukelić, D. Phytochemical Characterization of Polyphenols from Micromeria frivaldszkyana (Deg.)Vel. (Lamiaceae). Master's Thesis, University of Zagreb Faculty of Pharmacy and Biochemistry, Zagreb, Croatia, 2015.

31. Sargin, S.A.; Selvi, S.; Büyükcengiz, M. Ethnomedicinal plants of Aydincik district of Mersin, Turkey. J. Ethnopharmacol. 2015, 174, 200-216. [CrossRef] [PubMed]

32. Formisano, C.; Oliviero, F.; Rigano, D.; Saab, A.M.; Senatore, F. Chemical composition of essential oils and in vitro antioxidant properties of extracts and essential oils of Calamintha origanifolia and Micromeria myrtifolia, two Lamiaceae from the Lebanon flora. Ind. Crops Prod. 2014, 62, 405-411. [CrossRef]

33. Ozcan, M. Antifungal effects of Micromeria myrtifolia Boiss. \& Hohen. in Boiss. and Prangos uechtritzii Boiss. Hawsskn decoctions. Acta Aliment. Hung. 1999, 28, 355-360.

34. Porsolt, R.; Bertin, A.; Jalfre, M. Behavioral despair in mice: A primary screening test for antidepressants. Arch. Int. Pharmacodyn. Ther. 1977, 229, 327-336. [PubMed]

35. Rottenberg, J. The Depths: The Evolutionary Origins of the Depression Epidemic; Basic Books (AZ): New York, NY, USA, 2014.

36. Alpermann, H.G.; Schacht, U.; Usinger, P.; Hock, F.J. Pharmacological effects of Hoe-249: A new potential antidepressant. Drug Dev. Res. 1992, 25, 267-282. [CrossRef]

37. Delgado, P.L. Depression: The case for a monoamine deficiency. J. Clin. Psychiatry 2000, 61, 7-11.

38. Johannes, M.; Altmann, K.H. A ring-closing metathesis-based approach to the synthesis of (+/-)-tetrabenazine. Org. Lett. 2012, 14, 3752-3755. [CrossRef]

39. Guay, D.R.P. Tetrabenazine, a monoamine-depleting drug used in the treatment of hyperkinetic movement disorders. Am. J. Geriatr. Pharmacother. 2010, 8, 331-373. [CrossRef]

40. Garcia-Salas, P.; Morales-Soto, A.; Segura-Carretero, A.; Fernandez-Gutierrez, A. Phenolic-compoundextraction systems for fruit and vegetable samples. Molecules 2010, 15, 8813-8826. [CrossRef]

41. Khurana, S.; Venkataraman, K.; Hollingsworth, A.; Piche, M.; Tai, T.C. Polyphenols: Benefits to the cardiovascular system in health and in aging. Nutrients 2013, 5, 3779-3827. [CrossRef]

42. Farzaei, M.H.; Abbasabadi, Z.; Shams-Ardekani, M.R.; Abdollahi, M.; Rahimi, R. A Comprehensive review of plants and their active constituents with wound healing activity in traditional Iranian medicine. Wounds 2014, 26, 197-206.

43. Kumar, G.; Jalaluddin, M.; Rout, P.; Mohanty, R.; Dileep, C.L. Emerging trends of herbal care in dentistry. J. Clin. Diagn. Res. 2013, 7, 1827. 
44. Bjorkholm, C.; Monteggia, L.M. BDNF-A key transducer of antidepressant effects. Neuropharmacology 2016, 102, 72-79. [CrossRef]

45. Meng, X.; Zeng, N.; Zhang, Y.; Lai, X.; Ren, C.; Cheng, L. Effect of active constituents of Herba Epimedii on hypothalamic monoamine neurotransmitters and other brain functions in aging rats. Zhongguo Zhong Yao Za Zhi 1996, 21, 683-685.

46. Saraceni, M.M.; Venci, J.V.; Gandhi, M.A. Levomilnacipran (Fetzima) a new serotonin-norepinephrine reuptake inhibitor for the treatment of major depressive disorder. J. Pharm. Pract. 2014, 27, 389-395. [CrossRef] [PubMed]

47. Shen, Z.; Chen, Y.; Huang, J.; Hu, Z. The gene expression profile in hypothalamus-pituitary-adrenal-thymus (HPAT) axis from EF-treated old rats. Chin. J. Immunol. 2004, 20, 59-62.

48. Wedzony, K.; Chocyk, A.; Mackowiak, M. Potential roles of NCAM/PSA-NCAM proteins in depression and the mechanism of action of antidepressant drugs. Pharmacol. Rep. 2013, 65, 1471-1478. [CrossRef]

49. Xiong, Z.; Jiang, B.; Wu, P.F.; Tian, J.; Shi, L.L.; Gu, J.; Hu, Z.L.; Fu, H.; Wang, F.; Chen, J.G. Antidepressant effects of a plant-derived flavonoid baicalein involving extracellular signal-regulated kinases cascade. Biol. Pharm. Bull. 2011, 34, 253-259. [CrossRef]

50. Zhu, W.L.; Ma, S.P.; Qu, R.; Kang, D.L.; Liu, Y.D. Antidepressant effect of baicalin extracted from the root of Scutellaria baicalensis in mice and rats. Pharm. Biol. 2006, 44, 503-510. [CrossRef]

51. Souza, L.C.; de Gomes, M.G.; Goes, A.T.; Del Fabbro, L.; Carlos Filho, B.; Boeira, S.P.; Jesse, C.R. Evidence for the involvement of the serotonergic 5-HT1A receptors in the antidepressant-like effect caused by hesperidin in mice. Prog. Neuropsychopharmacol. Biol. Psychiatry 2013, 40, 103-109. [CrossRef]

52. Rinwa, P.; Kumar, A. Quercetin suppress microglial neuroinflammatory response and induce antidepressent-like effect in olfactory bulbectomized rats. Neuroscience 2013, 255, 86-98. [CrossRef]

53. Machado, D.G.; Bettio, L.E.B.; Cunha, M.P.; Santos, A.R.S.; Pizzolatti, M.G.; Brighente, I.M.C.; Rodrigues, A.L.S. Antidepressant-like effect of rutin isolated from the ethanolic extract from Schinus molle L. in mice: Evidence for the involvement of the serotonergic and noradrenergic systems. Eur. J. Pharmacol. 2008, 587, 163-168. [CrossRef]

54. Park, S.H.; Sim, Y.B.; Han, P.L.; Lee, J.K.; Suh, H.W. Antidepressant-like effect of kaempferol and quercitirin, isolated from Opuntia ficus-indica var. saboten. Exp. Neurobiol. 2010, 19, 30-38. [CrossRef]

55. Nakazawa, T.; Yasuda, T.; Ueda, J.; Ohsawa, K. Antidepressant-like effects of apigenin and 2,4,5-trimethoxycinnamic acid from Perilla frutescens in the forced swimming test. Biol. Pharm. Bull. 2003, 26, 474-480. [CrossRef]

56. Yi, L.T.; Li, H.M.; Li, Y.C.; Pan, Y.; Xu, Q.; Kong, L.D. Antidepressant-like behavioral and neurochemical effects of the citrus-associated chemical apigenin. Life Sci. 2008, 82, 741-751. [CrossRef]

57. Li, R.P.; Zhao, D.; Qu, R.; Fu, Q.; Ma, S.P. The effects of apigenin on lipopolysaccharide-induced depressive-like behavior in mice. Neurosci. Lett. 2015, 594, 17-22. [CrossRef]

58. Weng, L.J.; Guo, X.H.; Li, Y.; Yang, X.; Han, Y.Y. Apigenin reverses depression-like behavior induced by chronic corticosterone treatment in mice. Eur. J. Pharmacol. 2016, 774, 50-54. [CrossRef]

59. Ma, Z.G.; Wang, G.L.; Cui, L.; Wang, Q.M. Myricetin attenuates depressant-like behavior in mice subjected to repeated restraint stress. Int. J. Mol. Sci. 2015, 16, 28377-28385. [CrossRef]

60. Yi, L.T.; Li, C.F.; Zhan, X.; Cui, C.C.; Xiao, F.; Zhou, L.P.; Xie, Y. Involvement of monoaminergic system in the antidepressant-like effect of the flavonoid naringenin in mice. Prog. Neuropsychopharmacol. Biol. Psychiatry 2010, 34, 1223-1228. [CrossRef] [PubMed]

61. Yi, L.T.; Li, J.; Li, H.C.; Su, D.X.; Quan, X.B.; He, X.C.; Wang, X.H. Antidepressant-like behavioral, neurochemical and neuroendocrine effects of naringenin in the mouse repeated tail suspension test. Prog. Neuropsychopharmacol. Biol. Psychiatry 2012, 39, 175-181. [CrossRef] [PubMed]

62. Yi, L.T.; Liu, B.B.; Li, J.; Luo, L.; Liu, Q.; Geng, D.; Tang, Y.; Xia, Y.; Wu, D. BDNF signaling is necessary for the antidepressant-like effect of naringenin. Prog. Neuropsychopharmacol. Biol. Psychiatry 2014, 48, 135-141. [CrossRef]

63. Ito, N.; Yabe, T.; Gamo, Y.; Nagai, T.; Oikawa, T.; Yamada, H.; Hanawa, T. Rosmarinic acid from Perillae Herba produces an antidepressant-like effect in mice through cell proliferation in the hippocampus. Biol. Pharm. Bull. 2008, 31, 1376-1380. [CrossRef] [PubMed] 
64. Jin, X.; Liu, P.; Yang, F.; Zhang, Y.H.; Miao, D. Rosmarinic acid ameliorates depressive-like behaviors in a rat model of CUS and up-regulates BDNF levels in the hippocampus and hippocampal-derived astrocytes. Neurochem. Res. 2013, 38, 1828-1837. [CrossRef]

65. Kondo, S.; El Omri, A.; Han, J.; Isoda, H. Antidepressant-like effects of rosmarinic acid through mitogen-activated protein kinase phosphatase-1 and brain-derived neurotrophic factor modulation. J. Funct. Foods 2015, 14, 758-766. [CrossRef]

66. Petersen, M.; Simmonds, M.S.J. Rosmarinic acid. Phytochemistry 2003, 62, 121-125. [CrossRef]

67. Semwal, D.K.; Semwal, R.B.; Combrinck, S.; Viljoen, A. Myricetin: A dietary molecule with diverse biological activities. Nutrients 2016, 8, 90. [CrossRef]

68. Osigwe, C.C.; Akah, P.A.; Nworu, C.S.; Okoye, F.B.C. Apigenin: A methanol fraction component of Newbouldia laevis leaf, as a potential antidiabetic agent. J. Phytopharmacol. 2017, 6, 38-44.

69. Guragac Dereli, F.T.; Ilhan, M.; Kupeli Akkol, E. Discovery of new antidepressant agents: In vivo study on Anthemis wiedemanniana Fisch. \& Mey. J. Ethnopharmacol. 2018, 226, 11-16.

70. Steru, L.; Chermat, R.; Thierry, B.; Simon, P. The tail suspension test-A new method for screening antidepressants in mice. Psychopharmacology 1985, 85, 367-370. [CrossRef]

71. Hwang, K.H. Monoamine oxidase inhibitory activities of Korean medicinal plants classified to cold drugs by the theory of KIMI. Food Sci. Biotechnol. 2003, 12, 238-241.

Sample Availability: Samples of the compounds are available from the authors.

(C) 2019 by the authors. Licensee MDPI, Basel, Switzerland. This article is an open access article distributed under the terms and conditions of the Creative Commons Attribution (CC BY) license (http://creativecommons.org/licenses/by/4.0/). 